\title{
Hronika / Chronik
}

\section{Izvještaj o radu Centra za balkanološka ispitivanja ANUBiH u 2013. godini}

Težište aktivnosti Centra za balkanološka ispitivanja u 2013. godini bilo je na programu obilježavanja 50. godišnjice njegovog osnivanja. S priličnim naporima Centar je uspio realizirati sve planirane aktivnosti široko koncipiranog programa koji je usvojen u Centru još u novembru 2011. godine.

Početkom godine upućen je prijedlog BH Pošti za izdavanje prigodne poštanske marke u povodu obilježavanja 50. godišnjice Centra za balkanološka ispitivanja, a u saradnji s dizajnerom Tarikom Hodžićem, kreiran je logo i vizuelni identitet programa obilježavanja ovog značajnog jubileja.

Aktivnosti iz programa obilježavanja 50. godišnjice Centra započeli su promocijom tri izdanja Centra za balkanološka ispitivanja publikovana krajem 2012. i početkom 2013. godine, i to: monografije Antički sepulkralni spomenici sa područja Bosne i Hercegovine dr. Veljka Paškvalina i Religijske predstave prastanovnika južnoslovenskih zemalja akademika Alojza Benca te Godišnjak br. 41. za 2012. godinu. Promocija ovih izdanja je održana 4. aprila 2013. u prostorijama Akademije nauka i umjetnosti Bosne i Hercegovine, a promotori izdanja bili su prof. dr. Blagoje Govedarica, član ANUBIH i član Centra, prof. dr. Adnan Busuladžić, član Centra, i prof. dr. Salmedin Mesihović, vanredni profesor Filozofskog fakulteta Univerziteta u Sarajevu, a promociju je vodio akademik Dževad Juzbašić, direktor Centra za balkanološka ispitivanja ANUBiH. Promocija je bila jako dobro posjećena i medijski zadovoljavajuće popraćena.

Sastavni dio programa obilježavanja Centrovog jubileja bila je priprema publikacije 50. godina Centra za balkanološka ispitivanja ANUBiH s kompletnom bibliografijom svih Centrovih izdanja po uzoru na publikaciju objavljenu 1983. godine. Publikaciju su pripremile Melisa Forić i Minela Đelmo. Ovom prilikom su također sva Centrova izdanja digitalizirana te publikovana na DVD nosaču koji prati ovu publikaciju. Sva izdanja Centra su postavljena i na web stranici Akademije nauka i umjetnosti Bosne i Hercegovine za slobodno korištenje.

Izložba izdanja i djelovanja Centra za balkanološka ispitivanja ANUBiH upriličena je u Muzeju u Tešnju (27. septembra - 11. oktobra), Akademiji nauka i umjetnosti Bosne i Hercegovine (23-25. oktobra) Filozofskom fakultetu Univerziteta u Sarajevu (29. oktobra - 8. novembra), Filozofskom fakultetu Sveučilišta u Mostaru (1122. novembra) i Filozofskom fakultetu Univerziteta u Tuzli (2-13. decembra). Izložbom je dat osvrt na osnovne programske aktivnosti Centra, naučnoistraživačke projekte, kao i članove i saradnike koji su činili i dalje čine okosnicu njegovog rada. Na izložbi su prezentirani neki od eksponata arheološkog materijala, terenske i naučne dokumentacije s arheoloških, etnoloških i antropoloških istraživanja koje je Centar tokom niza godina sistematski sprovodio, a također su izložena i neka od najznačajnijih izdanja Centra za balkanološka ispitivanja koja i danas predstavljaju osnovnu literaturu kako za studente, tako i za naučnike koji se bave istraživanjem prošlosti i kulture Balkana. Autorica izložbe je Melisa Forić, stručna saradnica Centra za balkanološka ispitivanja ANUBiH, a konsultanti izložbe su akademik Dževad Juzbašić, prof. dr. Blagoje Govedarica, prof. dr. Esad Kurtović i mr. sci. Elma Hašimbegović. Dizajn panoa je osmislio i izradio Tarik Hodžić. Izložbe su imale jako dobar prijem kod publike, a ujedno su bile i prilika za obnavljanje saradnje s gorenavedenim institucijama, kojima su ovom prilikom i poklonjena neka od Centrovih izdanja.

Centralnu manifestaciju u široko osmišljenom programu obilježavanja Centrovog jubileja predstavlja Međunarodna naučna konferencija „Balkanologija danas“, koja je održana u Sarajevu 23-25. oktobra 2013. godine. Na konferenciji su s pozivnim referatima učestvovali: akademik Nenad Cambi (Hrvatska), prof. dr. Robert Donia (Sjedinjene Američke Države), akademik Esad Duraković (Bosna i Hercegovina), prof. dr. habil. Blagoje Govedarica (Savezna Republika Njemačka), akademik Dževad Juzbašić (Bosna i Hercegovina), doc. dr. Adnan Kaljanac (Bosna i Hercegovina), O. Univ.-Prof. Dr. phil. Karl Kaser (Austrija), prof. dr. Bernard Lory (Francuska), prof. dr. 
Dubravko Lovrenović (Bosna i Hercegovina), prof. dr. Friedrich Lüth (Savezna Republika Njemačka), dr. sci. Ante Milošević (Hrvatska), prof. dr. phil. Johannes Müller (Savezna Republika Njemačka), Emeritus professor dr. Robin Okey (Velika Britanija), Univ. Prof. Dr. Oliver Schmitt (Austrija), prof. dr. Holm Sundhaussen (Savezna Republika Njemačka), dr. Behija Zlatar (Bosna i Hercegovina). Iako su bili najavljeni, zbog bolesti i obaveza, prof. dr. Bernhardt Hänsel (Savezna Republika Njemačka), prof. dr. Ilber Ortayli (Turska), o. Univ.-Prof. Dr. Arnold Suppan (Austrija) i akademik Nikola Tasić (Srbija) nisu bili u mogućnosti prisustvovati konferenciji. U prvom dijelu konferencije iznesene su opšte i teoretske postavke o balkanologiji, a u drugom dijelu iznijeti su rezultati dosadašnjih istraživanja po hronološkim periodima. Razmatrana je problematika kulturnog razvoja balkanskih zemalja kroz praistoriju i istoriju te problem suživota kultura i civilizacija na ovom prostoru, kao i problem migracija i komunikacija, te svih drugih vrsta kontakata kroz različita razdoblja prošlosti, od praistorije do 20. stoljeća. Mnoga od ovih pitanja posljednji put su sistematski tretirana krajem 80-ih godina na naučnim skupovima koje je prvenstveno organizirala Akademija nauka i umjetnosti Bosne i Hercegovine i njen Centar za balkanološka ispitivanja, okupljajući stručnjake iz različitih država i okvira balkanoloških disciplina. U fokusu Konferencije bilo je i formuliranje strategije daljeg interdisciplinarnog razvoja balkanoloških studija u okviru historije, arheologije, lingvistike, antropologije, etnologije i drugih involviranih disciplina. Rezultati i zaključci Konferencije trebali bi biti osnov za osmišljavanje i pokretanje naučnoistraživačkih projekata na međunarodnom planu koji za cilj imaju istraživanja i promociju kulturne baštine Balkana i posebno Bosne i Hercegovine. Međunarodna naučna konferencija „Balkanologija danas“ bila je dobro posjećena, uz učešće naučnika i stručnjaka iz Bosne i Hercegovine, Hrvatske, Mađarske i Slovačke te velikog broja studenata Filozofskog fakulteta Univerziteta u Sarajevu. Konferencija je imala dobar prijem u javnosti zahvaljujući značajnom broju predstavnika medija iz BiH.

Za spomenute aktivnosti Centar je osigurao sredstva u ukupnom iznosu 46.800,00 KM, od čega je 40.400,00 KM uplaćeno na račun ANUBiH na ime održavanja Konferencije i obilježavanja jubileja, a sredstva u visini od 6.200,00 KM realizirana su direktnim plaćanjem. Održavanje Konferencije i pratećih manifestacija finansijski su podržali: Ministarstvo civilnih poslova Bosne i Hercegovine, potpredsjednik Federacije BiH gospodin Svetozar Pudarić, Ministarstvo kulture i sporta Kantona Sarajevo, Grad Sarajevo, Ambasada Savezne Republike Njemačke u BiH, Ambasada Republike Francuske u BiH, Fondacija Heinrich Böll, Regionalni austrijski ured za naučnu i kulturnu saradnju Sarajevo, Lutrija BiH te Savjet za nauku Ministarstva obrazovanja, nauke i mladih Kantona Sarajevo.

Svečana sjednica Centra za balkanološka ispitivanja ANUBiH kojoj su po prvi put nakon više od dvadeset godina prisustvovali i članovi Centra izvan Bosne i Hercegovine održana je 25. oktobra 2013. godine. Na sjednici su razmatrani izvještaji o djelovanju Centra u proteklom periodu i perspektive njegovog daljeg razvoja u budućnosti. Razmatrano je pitanje proširivanja članstva, mogućnosti iznalaženja podrške za nesmetano dalje djelovanje Centra, u čemu izdavaštvo i naučnoistraživački projekti imaju prioritet. Zaključeno je da bi osnovna djelatnost Centra u narednom periodu trebalo da obuhvati dalje redovno izdavanje Godišnjaka, publikovanje Ličnih zabilješki generala Oskara Potioreka, završetak projekta digitalizacije Kartoteke grobova prastanovnika zapadnog Balkana i organiziranje konferencija s balkanološkim temama, po uzoru na ovu organiziranu 24 . i 25. oktobra 2013. godine. Otvorena je mogućnost da se sljedeća balkanološka konferencija održi u Splitu u saradnji s Muzejom hrvatskih arheoloških spomenika. Također, unutar Akademije nauka i umjetnosti Bosne i Hercegovine pokrenut će se procedura da Centar za balkanološka ispitivanja ANUBiH bude partner Univerzitetu iz Kiela za realizaciju projekta Istraživanja neolitskih populacija u dolini Drine, kao i izdavanje publikacije o istraživanju neolitskog lokaliteta u Okolištu kod Visokog, odnosno njenog prevoda s njemačkog na b/h/s jezik.

Krajem godine u Centru se radilo na pripremi Godišnjaka br. 42 za 2013. godinu u kojem je prema ranije utvrđenom planu predviđeno objavljivanje referata i diskusije s Međunarodne naučne konferencije „Balkanologija danas“. S obzirom na to da je Redakcija Godišnjaka primila veliki broj radova za objavljivanje u Godišnjaku, odlučeno je da se početkom godine publikuje i redovni broj Godišnjaka s do sada pristiglim radovima, koji će nositi broj 43. za 2014. godinu, te se paralelno radilo i na pripremi ovog redovnog broja. Sredstva za izdavanje Godišnjaka kao i svake godine su osigurana od strane Rimsko-Germanske komisije Njemačkog arheološkog instituta iz Frankfurta na Majni, a aplikacija je upućena i Fondaciji za izdavaštvo/nakladništvo Sarajevo.

Osim ovoga, u Centru za balkanološka ispitivanja ANUBIH se tokom cijele 2013. godine intenzivno radilo na realizaciji projekta izdavanja Ličnih zabilješki generala Oskara Potioreka čime će Akademija nauka i umjetnosti Bosne i Hercegovine i njen Centar za balkanološka ispitivanja dati svoj doprinos obilježavanju 100. godišnjice od početka Prvog svjetskog rata. Akademik Dževad Juzbašić u saradnji s prof. dr. Zijadom Šehićem je odabrao i obradio materijal ličnih zabiljeških generala Oskara Potioreka o unutrašnjopolitičkoj situaciji u Bosni i Hercegovini od 1911. do polovine 1914. godine, koji će se uz komentare i opširan uvod na bosanskom i njemačkom jeziku publicirati u okviru Posebnih izdanja ANUBIH, odnosno Centra za balkanološka ispitivanja polovinom 2014. godine. 
Krajem godine Centar za balkanološka ispitivanja ANUBiH potpisao je ugovor o saradnji s Institutom za orijentalnu i evropsku arheologiju Austrijske akademije nauka. Saradnjom će biti obuhvaćeni projekti zajedničkih arheoloških istraživačkih projekata, organizacija naučnih skupova, razmjena naučnika te izdavanje zajedničkih publikacija u oblasti arheologije. Za voditelja aktivnosti u budućim projektima unutar navedene saradnje imenovan je prof. dr. Blagoje Govedarica, član ANUBiH i član Centra za balkanološka ispitivanja ANUBiH. Centar je na ovaj način proširio listu međunarodnih institucija s kojima intenzivno sarađuje uz ocjenu da ovakva vrsta sarad= nje, pogotovo u domenu zajedničkih istraživačkih projekata, može doprinijeti daljem radu Centra za balkanološka ispitivanja kako na trenutnom, tako i dugoročnom planu. 